\title{
Education and the Pandemic: Distance Learning and the School-Family Relationship
}

\author{
Educación y pandemia: el aprendizaje a distancia y la relación escuela-familia \\ Educació i pandèmia: formació a distància i relació escola-família
}
Giorgio Crescenza ${ }^{1, *}$, Massimiliano Fiorucci ${ }^{1}$, Maria-Concetta Rossiello ${ }^{2}$, Lisa Stillo ${ }^{1}$

1 | Department of Education, Università di Roma Tre, Roma, Italy

2 | Department of Economy, Management and Territory, Università di Foggia, Foggia, Italy

${ }^{*}$ Corresponding author: crescenza.doc@gmail.com (Giorgio Crescenza)

Received: 04/08/2020 | Accepted: 01/12/2021 | Published: 01/20/2021

\begin{abstract}
In this paper we present the preliminary results of a survey administered to Italian students, teachers and families to detect the conditions prevailing in the education sector in the time of Covid-19. The aims of the study were to analyze teachers' new citizenship skills and families' relationship skills in order to create a new school-family agreement that is suitable not only for face-to-face lessons but also for distance learning and that incorporates new participation competences from all those involved. Responses to the questionnaires, created in semi-structured format, were received from 2,000 teachers, families and students from all over Italy. This explorative phase highlighted the profound distance-learning revolution that has been adopted by over $90 \%$ of education systems but that has also created enormous difficulties from the emotional and relational perspectives. Aspects such as personalization and individuality in the learning process have been deferred, especially for those with disabilities. The conclusions intend to open to feasible socialpedagogical projects that respond to educational, digital and social needs drawn from this research, heralding that the pandemic has brought us into a new age of education.
\end{abstract}

KEYWORDS: school; COVID-19; distance learning; quali-quantitative research; citizenship; social skills

Citation: Crescenza, G., Fiorucci, M., Rossiello, M.C. y Stillo, L. (2021).

Education and the Pandemic: Distance Learning and the School-Family Relationship. Research in Education and Learning Innovation Archives, 26,73-85. 10.7203/realia.26.18078

Copyright: The Authors. Open Access: This article is distributed under the terms of the Creative Commons Attribution-NoDerivatives 4.0 International licence (CC BY-ND 4.0)

Funding: None informed
RESUMEN: Este artículo expone los resultados de una encuesta dirigida a estudiantes, profesores y familias en Italia, encuesta cuyo objetivo es detectar las condiciones de cada categoría en tiempos de Covid-19 en la escuela. El objetivo de este trabajo es investigar las nuevas competencias del docente, además de las competencias de relación de las familias que son básicas para un nuevo pacto de corresponsabilidad escuela-familia no solo en la didáctica en presencia, sino, también, en la formación a distancia, incluyendo nuevas competencias de participación por parte de todos. Para llevar a cabo esta investigación se han elaborado cuestionarios semi-estructurados dirigidos a docentes, familias y estudiantes por un total de 2,000 respuestas recibidas de todas partes de Italia. La investigación en la primera fase explorativa destacó la gran revolución de la didáctica a distancia adoptada por más del $90 \%$ de los sistemas educativos. Sin embargo, dicha didáctica ha creado grandes dificultades en los aspectos emotivos y relacionales. La personalización y la individualidad del proceso de aprendizaje se ha dejado de lado sobre todo para aquellos que sufren una discapacidad y forman parte de la gran área de necesidades educativas especiales. Las conclusiones pretenden abrirse a posibles proyectos socio-pedagógicos que respondan a necesidades educativas, digitales y sociales extraídas de esta investigación, anunciando que la pandemia nos ha llevado a una nueva era de la educación.

PALABRAS CLAVES: colegio; COVID-19; aprendizaje a distancia; investigación cuanti-cualitativa; ciudadanía; habilidades sociales 
RESUM: Aquest assaig exposa un primer reconeixement d'una enquesta dirigida a estudiants, professors i famílies del territori italià, que té com a objectiu detectar les condicions de totes aquestes assignatures en el moment de CoViD-19 en el món escolar. Els objectius d'aquest treball són investigar les noves habilitats de ciutadania del professorat i les habilitats relacionals de les famílies per tal de crear un nou acord escola-família, que siga adequat no només a les lliçons en viu, sinó també a l'ensenyament a distància, incloses les noves competències de participació per part de tots. Per dur a terme aquesta investigació, s'han elaborat qüestionaris en format semiestructurat adreçats a professors, famílies i estudiants per a un total de 2.000 respostes rebudes de cada part d'Itàlia. La investigació de la primera fase exploratòria va posar de manifest la gran revolució de l'aprenentatge a distància adoptada per més del $90 \%$ dels sistemes educatius. No obstant això, havia creat grans dificultats en els aspectes emocionals i relacionals. La personalització i la individualitat del procés d'aprenentatge s'ha deixat de banda sobretot per a aquells que tenen discapacitats. Les conclusions pretenen obrir-se a projectes sociopedagògics factibles que responguen a les necessitats educatives, digitals i socials extretes d'aquesta investigació, que anuncia que la pandèmia ens ha portat a una nova era educativa.

PARAULES CLAU: col-legi; COVID-19; aprenentatge a distància; investigació quanti-qualitativa; ciutadania; habilitats socials

\section{Practitioner Notes}

\section{What is already known about the subject}

- The distance learning, teacher training and educational relationship represent important issues of education. Distance learning is fundamental to integrate traditional learning, but in Italy is not yet developed enough. At the same time, the educational relationship between school and parents should be a pillar of school experience, nevertheless school and parents are often in contrast with each other. During the Covid-19 crisis, these aspects have change radically.

\section{What this paper adds}

- Our first reflections are useful to broaden the horizon of pedagogical and didactic perspectives during and post Covid-19 crisis. Thanks to an exploratory / descriptive phase we investigate how the school, students and families have had to rethink themselves within the educational path, which is largely confused and precarious.

\section{Implications of this research and/or paper}

- The distance learning, and in general the alternative educational proposals tested as well as a renewed school-family relationship, must remain the core of pedagogical and political debate. Especially in this moment of health and social emergency, we need to address studies and research to build a new common pedagogical prospective, in order to plan the near future, which is still uncertain more than ever.

\section{INTRODUCTION}

The closure of schools of all levels in Italy has constituted an inevitable measure in an attempt to reduce the phenomena of contagion by the Corona virus. It was a burdensome yet very delicate measure on the social level not only because this produces, at least in current proportions, not only an irreparable damage in the cultural preparation of our students, but because it highlights, much more than any other message, the overall significance of the situation. A closed school is not just a closed building.

It is a community that suddenly disappears in that territory. It is that place where kindergarten and primary school children meet every morning to learn, play, share and spend a day together with their teachers while their parents meet, confide, tell. It is that place where middle and high school students meet every morning to comment on the day, reveal fears and hopes, talk about their passions and interests, confront and collide, get passionate and sometimes even get bored. It is that place, unique and 
unrepeatable, where the old and new generations meet each morning experimenting with meaningful relationships and where you learn by sharing knowledge and experiences (Cambi, 2006; Frabboni, 2009).

It was therefore decided to develop a survey aimed at students, teachers and families that is focused on detecting the conditions of all these subjects at the time of Covid-19 in relation to the world of school (Cohen, Manion, \& Morrison, 2007). Specifically, the objectives of the survey, carried out through three different questionnaires addressed to teachers, families and students were the following:

- Exploring how the relationship of families with students and the school had changed and what skills the parents themselves had to put in action;

- Investigating the educational relationship between teacher and student and the positive or negative impact of teachers' pedagogical skills in this new scenario;

- Analyzing the relationship of students with school and family during the distance teaching period, as well as the impact of the lockdown to their daily lives.

Distance learning became suddenly essential in this emergency phase but it was precisely an emergency teaching where everyone was able to rely solely on their own resources without there being a pedagogical and didactic planning behind them. It is important to be aware of this: it was not a thoughtfully planned and organized distance learning that, in any case, had the capacity to integrate and support yet never to substitute live or face-to-face teaching which is the heart of an educational relationship. Furthermore, in addition to the limits of the teaching method carried out in this period, some of its potentials should also be identified, on which, one should reflect serenely without a sense of Manichaeism.

The limits of Online Distance Learning, especially for how it was organized, were evident because it appeared to be de-contextualized. Everyone was left alone in front of their working station. The context of education is not only a physical space, it is also a symbolic place, arousing an experience full of signs and symbols that give meaning to everyday experience. Just think of the use of walls in schools and not only in primary schools: posters, collective works, travel photos are hung. The walls, thus become the place of that shared memory that disappears in the ODL, especially if it is not designed but adopted in a supplementary form.

Many in this phase have argued that distance learning creates inequality. In reality, as Gino Roncaglia has appropriately observed, distance learning does not create inequalities: it makes them emerge, it makes them come to light in a more evident way, and it reveals them (Roncaglia, 2020).

Therefore, the research I have conducted together with Giorgio Crescenza, Maria Concetta Rossiello and Lisa Stillo, not only has intended to investigate the above, but also to compare the different socio-environmental and cultural situations of the people who completed the different questionnaires. The "final diagnosis" can and will be useful for improving the quality of educational and teaching work in the school, as well as offering numerous pedagogical tracks for further study, most especially in this time of a global crisis.

\section{METHODS}

The research faced the constrains imposed by the quarantine for the Covid-19, hence we have decided to adopt a quantitative descriptive exploratory design (Benvenuto, 2015). This kind of approach has allowed us to achieve a wide sample which has given us the possibility to broaden the comprehension and the analysis of the phenomena studied. Specifically, we carried out three different web surveys which involved parents, students, and teachers who live in three different geographical areas of Italy: 
the North, Central Area and the South. In this way, we are able to explore many various perspectives and experiences of people during Covid-19, since Italy is a plural and heterogeneous country, with many social, cultural, economic and political differences, which varies according to territories and cities. The survey aims to explore the following issues:

- Relationship among school/teachers, parents and students

- Distance learning

- Quality of teaching inclusion

- Critical Issues and Future Developments

With this method, we have obtained a large number of data by which it is possible to describe many different points of view about school life during the quarantine. Even though the sample is not fully representative and the findings cannot be generalized, we will be able to get significant results through the statistical analysis of data. Thus, the relations among the multiple variables will provide important information which will serve as a basis for future research (Franco, 2010).

The web survey was sponsored through different channels: Facebook, trade unions, schools and so on, because the aim was to obtain as much as possible respondents and information, in order to keep numerousness and heterogeneity.

\subsection{1 Description of Context and the participants}

The survey was conducted fundamentally on three regions of the country in order to represent the different areas of the national geographical context: Lombardy, Lazio and Apulia. These are three contexts of very different areas in terms of economy, services and socio-cultural development. Lombardy, the most populous, is the most dynamic and productive region in Italy, but it has also been the one most affected by the pandemic, both in terms of contagion and of victims. Lazio ranks demographically in third place among the Italian regions after Campania and Lombardy. Apulia, in the south, less populous and less affected by Covid-19 than the previous regions.

A total number of 991 parents responded to the survey on the condition of families, including 826 women (83.4\%) and 165 men (16.6\%). From the data, it is clear that for this survey, the participation in Lazio was most numerous, with 628 respondents (64.4\%), Puglia with $240(24.2 \%)$ and subsequently Lombardy with 82 (8.3\%). The most representative sample of parents, as can be seen from Fig. N. 1 was that whose children attend primary school (56.9\%) which if added to that of kindergarten (6.5\%) is indicative of $2 / 3$ of the interviewees.

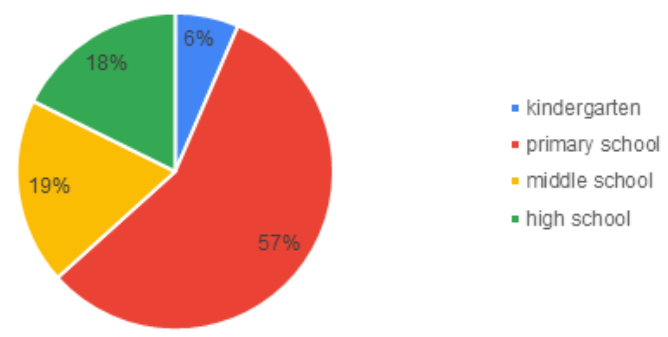

Figure 1. School attended by pupils of interviewees

The figure is emblematic of the situation, because in the case of distance learning for the little ones the parents were fundamental and had to replace much more than 
the "real school". In kindergarten and primary school, educational paths are implemented which prepare for training, using a didactic system which, although developed with heuristic methods, rests on solid foundations in which the pedagogical aspect is prevalent, if not exclusive and which is the best experience in the laboratory. In workshop activities, the teacher not only promotes learning by doing, but stimulates student discussion on the experience in progress, thus fueling a very fruitful sociocognitive conflict (Dewey, 1915) for intellectual growth. None of these can take place in the ODL and trying to teach children what they are unable to learn determines a substantial loss of self-esteem, interest and time. Resources that must be destined to enhance the characteristics that the brain has at the highest degree in childhood, for example emotional intelligence and memory, and which, if not cultivated, are likely to be dispersed (Montessori, 2000).

A total number 794 subjects participated in the survey on the condition of teachers during COVID19: 674 women (84.9\%) and 120 men (15.1\%). A fact that expresses the phenomenon of the strong feminization of the school in contrast with what happened in the past (Chiosso, 2011; Covato, 1996). The sample of interviewees has a different distribution as compared to families: Lazio with 320 (40.3\%), Lombardy with 277 (27.3\%) and Apulia with 201 (25.3\%). There is also a higher presence of teachers who teach in primary school, but the other school grades are distributed proportionally, compared to the students enrolled.

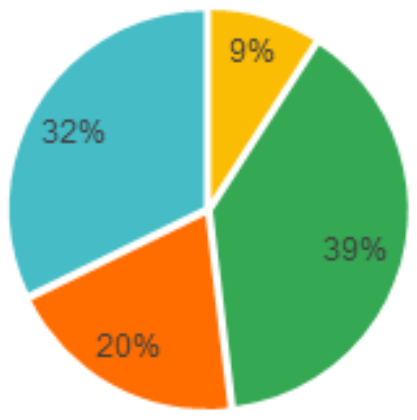

" kindergarten

- primary school

- middle school

- high school

Figure 2. Order and degree of teaching

In the survey on the condition of upper secondary school students, 623 pupils participated, including 422 female (64.9\%) and 228 male (35.1\%). The sample of the interviewees is proportionally distributed with respect to the student population: Lombardy with 257 (39.5\%), Lazio with 224 (34.5\%) and Puglia with 162 (24.9\%). Students are distributed by type of school attendance: Technical Institute (28.2\%), Professional Institute (19.7\%), Scientific High School (19.1\%), Linguistic High School (14.6\%), Human Sciences High School (9.2\%), Artistico High School (5.8\%) and Classical High School $(3.2 \%)$.

\subsection{2. Questionnaires}

In order to investigate the issues outlined above, three questionnaires were implemented. Each one is composed of different aspects with the aim of exploring the social and personal variables, the distance learning issues and the difficulties experienced by students, teachers, and parents during the period of Covid-19 related to teaching, learning and the relationships. Since this is an explorative and descriptive research, each questionnaire also includes some open questions, so as to allow the respondent to deepen and broaden their answers (Corbetta, 2003). In fact, open-ended questions are useful to better analyze complex issues in explorative studies (Bailey, 1994).

Generally speaking, questionnaires have both critical and positive elements. On one hand, closed questions are presented, which can be quickly answered and can be 
easily coded, However on the other hand, the questionnaire cannot be exhaustive and the open-ended questions can often give rise to some irrelevant information which make the analysis more complex (Cohen et al., 2007).

The questionnaire for teachers is composed of four areas of investigation:

- Personal information area;

- Distance learning area;

- Relationship with students area;

- Digital teacher training area;

The questionnaire for parents is composed of three areas of investigation:

- Personal information area;

- Family relationship area;

- Relationship with school area;

The questionnaire for students is composed of three areas of investigation:

- Personal information area;

- Family relationship area;

- Distance learning area;

- Relationship with school area;

\subsection{Procedure}

The distribution and information work of the questionnaires took place entirely online through the Google platform. The modules have been open for a few weeks, that is, from 21 May 2020 to 10 June 2020. Their dissemination took place thanks to the active collaboration of the ProteoFareSapere Association and the FLC CGIL of the geographical areas concerned, as well as the availability of some School Principals who have scrupulously invited the recipients to participate. Participation in the survey went beyond expectations, because the research group had hypothesized a sample of 2000 subjects, which ultimately totaled 2408 , including parents, teachers and students.

\section{EXPECTED RESULTS. A FIRST RECONNAISSANCE}

From an initial analysis of the three questionnaires made for the families, teachers and students of our survey sample, it is possible to trace the initial figures of results that appear as positive as negative, at times antinomy and often consequential of an emergency situation that seem to have radically changed not only the approach to teaching but also the relationships, responsibilities and skills that parents, teachers and pupils suddenly found themselves having to respond to.

As it is known, the purpose of a questionnaire is to access the world of life, the lived experience (Creswell, 2014) of people chosen precisely on the basis of 'substantive' representativeness to trace the positive and negative aspects of an ongoing change.

On one hand there are the positive results as teachers, families and students agree that in this historical moment, digital skills have proven to be not only necessary but essential to respond to the emergency and that, having overcome this moment of global crisis, certainly it will be necessary to comply with educational institutions and professionals, with cognitive and training standards in the field of digital skills (Calvani, 2017; Raja, 2016). In fact, technology has allowed the participation in school 
culture, greater exchange within the educational institution and forms of collaboration and sharing of know-how have been promoted in many cases. $90.4 \%$ of the teachers interviewed are convinced that the emergency teaching experience from Covid-19 will certainly contribute to their teaching professionalism as regards the use of new technology and ODL. Through an open question, an attempt was made to investigate this aspect: almost half of the respondents (44\%) identified the improvement of digital and organizational skills as an important contribution during the emergency period, while $26 \%$ said it represented an enriching moment due to the novelty and source of educational innovation. During the pandemic phase, $17 \%$ identifies a useful contribution in the process of being able to report what they have learned in the "normal" school, when it will be possible to return in the face-to-face lessons.

However, the negative figure of this scenario was the change in relationships and inter-trans-personal and professional exchanges. Again through an open question, teachers who have identified in the emergency period, a moment without positive contributions for professional enrichment, specify the reasons in two aspects: the absence of physical relationship (26\%), and the non-existence of the "real" school, since "ODL is not the school" $(24 \%)$. The biggest problem noted both from families and teachers is related to the involvement of students in teaching. A good percentage of families stressed that ODL made their children more restless and more likely to be distracted, also the teachers often stressed that "distance learning compromises relationships and superficially reaches the pupil" or even that "it has not been possible to always work actively and dynamically with the students".

This aspect that becomes more relevant in pupils with disabilities, DSA or Special Educational Needs, where the teachers emphasize (31.2\%) that only rarely have they managed to deal with students with disabilities, DSA or BES with scarce targeted interventions. The same goes for foreign students with whom, in many cases there has been a deterioration in communication but a more or less unchanged relationship with their families. This underlines that there is still a lot of work to be done in the field of disability technologies (Carruba, 2014). Technologies start from the assumption that the disabled person is not always the one who cannot do it, but the one who uses different strategies from ours. The school cannot - now more than ever - certainly escape the commitment to education for all, it cannot fail to know the tools that can facilitate teachers and pupils in acquiring skills (Calvani, 2019).

The students, in line with Figure 3, proved to be more critical and as it can be seen in the following graph, $83.9 \%$ underlined that there has been no targeted interventions envisaged according to their needs, making it the most important figure of this research.

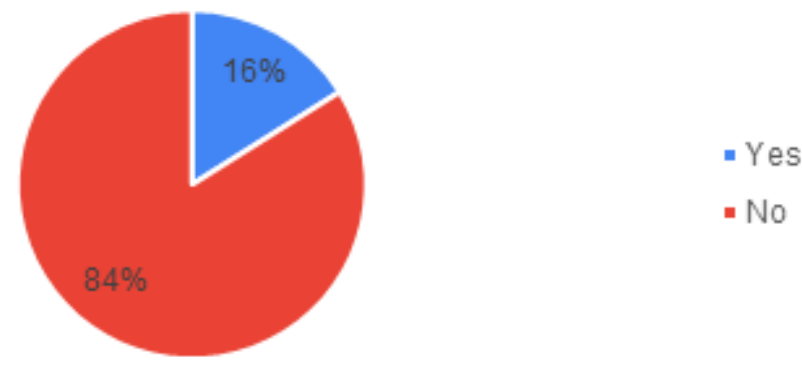

Figure 3. Needs of students. Answer to: "Are there targeted interventions according to your needs?" 
Returning to the contrast between negative figures and positive figures, it can be affirmed that there is a certain homogeneity of responses from the different subjects involved in the research stating that in this emergency situation there was no lack of availability of teachers to be contacted both by families and by students. In fact, $62.6 \%$ of them say that as regards distance communication, contacting teachers was quite simple and $69.5 \%$ said that the teachers responded at any time and expressed availability. Communication between the faculty members also seem to have worked effectively. As can it be seen from the graph (Figure 4), there have been numerous exchanges relating to both the use of technological tools and a useful exchange of general information. The same, even if not represented by the graph, can be said in relation to teaching and the difficulties encountered, testifying to solidarity at school, which manages to network and support itself despite the precarious situation.

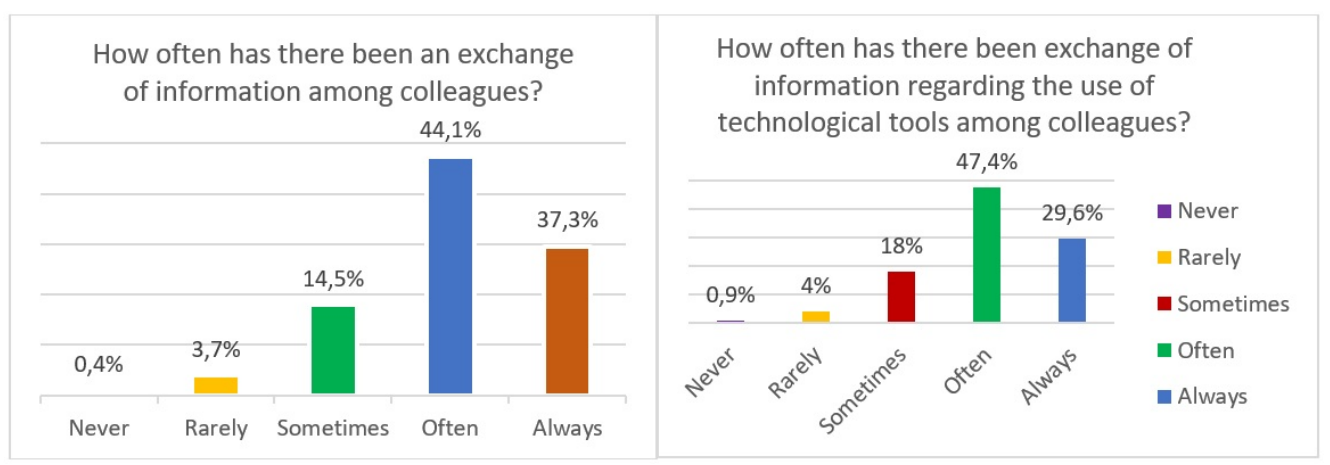

Figure 4. Relations among teachers

This important sign that denotes in this critical situation how much the teachers felt the need of the competence of "good communication" which is fundamental in the activity of a teacher (Volpicella, 2020b) and which allows to live the "space of relationship" differently (Volpicella 2020, 43) in this circumstance surely distorted but not forgotten. Another important revelation, in fact, and which we can affirm is part of the positive figures of this survey, is a good $48 \%$ of the teachers who felt as their main objective - in this delicate historical moment - that of arousing self-confidence in the pupil with a significant detachment from a subsequent $21.3 \%$ who considered it essential to adequately prepare each student for the next school year.

As a consequence to what has been said so far is a greater sense of responsibility that has empowered, albeit in a different way, all the interviewees. On a value scale from 1 to 6 points, the teaching staff is positioned with a good $60.6 \%$ between the fourth and fifth steps of this scale, affirming a sense of responsibility felt in a stronger and at times a serious way, proving tiring and exhausting in carrying out one's role at a distance. The same sense of responsibility linked to an evident difficulty is registered among the students: $63.2 \%$ said that they often found themselves alone having to decide on the organization of didactic activities at home, lacking acknowledgment of time and activities done during face-to-face lessons to the point that $41.2 \%$ replied that parental involvement was useful and necessary to facilitate its understanding and implementation in the home environment.

This is the background scenario to a rather relevant datum that we have so far extrapolated from the analysis of the data concerning families (as can be seen in fig. 5) which have underlined that they feel quite overloaded in this period of health emergency $(42,2 \%)$ and who often felt they did not have the adequate skills that comply with the school and technological commitment required by their children, or better by ODL (35.6\%).

In this case, the reference to the school-family co-responsibility pact is inevitable (Baldacci, 2014a; Doniti, 2015; Pati, 2008; Volpicella, 2017) which today most 


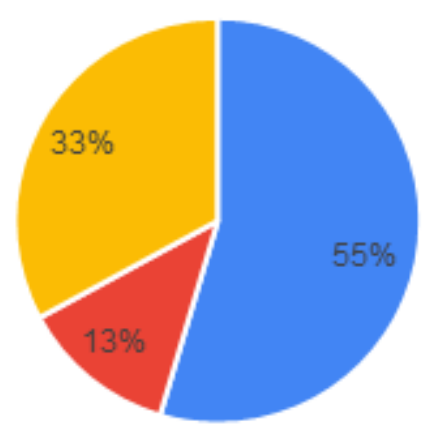

- Yes, it has increased

- No, it has decreased

- Has not changed

Figure 5. Participation of parents in school educational path.

need joint action and shared teaching to contribute to the full development of the life plan of each child / student, the citizens of tomorrow. Unfortunately, this pedagogical perspective still does not find a concrete place in the school-family relationship and this emergency situation has contributed to exacerbating it since $78.3 \%$ of families replied (fig. 6) that they had to fill the roles and functions of the teachers at home in the absence of an adequate and previously shared educational strategy.

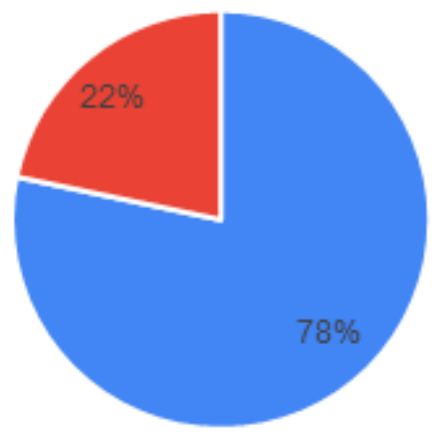

Figure 6. Role of parents in education path of children. Answer to "Have you ever taken on the role of teacher during this period?"

The shift of educational activities from the classroom to the home environment during a general lockdown, through remote-working and smart-working processes, has resulted in a spatial and temporal "overcrowding", preventing numerous families from being able to support their children adequately and requiring an enormous effort in terms of organization and management. About half of the respondents (541) said they were unable to combine their work with the commitments at school; a part of the sample claims to have difficulties in managing time and space. While this issue may not be of primary importance when referring to families with older children, for all primary school students the contribution and emotional and practical support from their parents seems to be essential and therefore deserves greater attention. The emergence of these critical issues highlights the lack of adequate family policies to support the needs (not only the evident financial aspect) of our families, an aspect that deserves a greater socio-psycho-anthro-pedagogical study. Also, through the parents' answers, it is possible to identify some critical situations experienced by their children, in particular regarding the difficulty in orienting themselves among the activities, tasks assigned and in organizing the system of study in an adequate way. Answers of the same type are encountered in the first analysis of the questionnaire addressed to students wherein the aspects of organization of time, space and didactic activities 
are the elements of the greatest difficulty. Again, as regards students, just over half (53\%) judged the workload to be excessive, in terms of questions, homework, etc., even though the percentage of those who experience moments of evaluation as being most anxious is minimal. As far as students are concerned, albeit at a distance, a condition of solidarity and mutual support seems to have been created: almost all of them say they collaborate and help each other with their classmates in terms of school work. In general, the aspects related to the didactic dimension, report elements of criticality, as expected, but also aspects of positive resilience, in an arduous moment from many points of view, in which the known boundaries have disappeared in many situations, giving way common sense and a feeling of mutual help and support. It is precisely the aspects linked to the relational dimension, of which educational practice is nurtured and nourished, that seem to be the elements that more than others have allowed a concrete and important response to critical issues.

What emerged seems to allow us to hypothesize that, although the lack of effective connections and adequate devices has been present and has influenced the learning paths, the relationships between the different protagonists of the school have nevertheless been created, albeit with the obvious limits and consequent difficulties. Compared to this, almost all of the students who answered the questionnaire state that they miss their classmates $(79.7 \%)$ and the constant dialogue with their teachers (52.5\%); as well as the didactic activities carried out in the classroom (55.4\%). If these evidences do not seem surprising, they can help to support a debate that still too often sees the contrast of distance learning with face-to-face teaching, which can never be replaced, both in its teaching / learning function and in its function of socialization and personal growth.

Relationships are a fundamental part of the educational practice and growth of everyone, and their construction requires spaces for meeting, confrontation and contact, as well as the construction of knowledge, which are socialized also and above all thanks to the exchange and work with their classmates, among the desks of the school walls. This element remains a point of fragility of this moment, wherein relationships in their concreteness have disappeared, but it has also represented an element to cling to and through which to build spaces and resources useful for resisting in a moment of emergency and precariousness.

\section{CONCLUSION}

At the conclusion of this first survey, however, it is certainly possible to affirm that ODL has revolutionized an entire socio-affective and relational system, which has radically changed the space and time of training, sharing and management. It is not just teaching but involving in a new social order for families and schools, teachers, parents and students, offering a different scenario that poses new and urgent challenges to our family and school welfare system, both economic and social.

The school after the pandemic can no longer be considered the same as relational, cognitive and affective as social systems have been altered. This is demonstrated above all by the re-elaborations of the qualitative data of this research where we have observed that the parents have requested greater domestic involvement and greater responsibility from their children (85\% of the interviewees) and, in a diametrically inverse way, the children have needed support, guidance and comparison by parental figures not only in carrying out tasks. The teachers ( $65.4 \%$ of the interviewees) considered it necessary to give more space to the emotional needs of students and families even though, at times, they felt they did not have adequate skills to carry out this role and, as a consequence, they strongly felt the need for psycho-pedagogical support for the development of a profession that many teachers believe and we quote "It is changing in an irreversible way, we are at an epochal turning point in not only professionally 
but also our personal training". Specifically, teaching is based on the autonomy of the pupils, who don't be leaved alone (Margiotta, 2018) it is a personal work in a collective path, shared with classmates and followed by teachers in every steps of learning. Teachers realizes the difficulties of the pupils and intervenes, supporting, reassuring, and taking care of them. In light of the above, in the ODL is important to be more careful and develop further competences in order to prevent pupils from feeling alone.

The teachers training remains a central point on which it is still necessary to work from a digital skills perspective, but not only; it seems useful to hypothesize a training that allows teachers to grasp the innovative aspects of the discoveries in many fields of knowledge, which can help them to better understand and innovate educational and didactic practices. The ODL model, has been little used in Italy, and "clumsily" used in a moment of need, must become a space of possibility to the construction of greater inclusion and protagonism of students, rather than aseptic non-place for the transmission of knowledge and the reproduction of the inequalities already present in the society (Ferrari, 2020; Unterhalter \& North, 2017). Recently, Rivoltella (2020) claimed that the physical classroom and the digital classroom are not be opposite horizons and not mutually exclusive, but they can be perceived as coexisting dimensions; what needs to be rethought depends, perhaps, on educational intentionally or on planning understood as an essential meta-competence to the educational practice itself (Milani, 2014). This means that the new challenge launched to those who are involved in pedagogical and didactic planning focuses on "how" to promote planning and to outline a possible model for an educational itinerary of transformative learning in a plurality of contexts that arise on different levels. A particular planning space must be reserved for the theme of disability where the "educational isolation" and the sense of loneliness are mostly widespread. The burden of the inadequacy of ODL to respond to personalized and individualized educational paths struck above all and most importantly the families of disabled children / young people. Some parents claim to have often requested work permits in order to support their children in teaching, others have made use of individual interviews with teachers to be able to receive targeted tasks such as diagrams, maps, etc. However, this was not enough and it is precisely among students with disabilities that the highest data of restlessness (54.6\%), distractibility (35.4\%) and disinterest in the activities proposed during the "virtual" lessons are recorded, which open up to the "Communication revolution", as Baldacci (2020) defines it in which we are all involved and with which we must deal to rethink the entire educational system. In fact, from a first analysis, the needs of every citizen emerges in a society of information and communication are: the need to be informed, the need to interact, the need to express oneself, the need for protection and the need to manage complex situations related to technological tools and digital environments. Also, for this reason, the second phase of the research will articulate the actions for the design of an inclusive training curriculum also to the digital and transversal citizenship skills that actively involve all the subjects of a training process, protagonists of this research.

For this reason, it is necessary to add broader considerations that are connected to the school crisis, preceding to the health emergency. School lacks an explicit and organic idea (Baldacci, 2014b), both on the cultural and pedagogical level, as well as on the organizational and management. About this, through this exploratory investigation we are able to reflect on some issues.

First, the dimension of school-family educational co-responsibility and the construction of a common feeling of society, as an educating society, seems to be a rediscovered value of recent months. But, this entails that normally it is a forgetted dimension within the pedagogical practices. It is instead one of the indispensable tools to promoting school as a community and community as a school, within a circu- 
larity of exchange, reciprocity and construction of a plural, democratic, participatory outlook (Bruzzone, 2016).

Secondly, the dimension of the importance of children and young people, who are often only passive actors of proposals that make them consumers of products, rather than co-builders of their own growth path, requires further attention, starting precisely from what has been experienced in this period of loneliness.

This year of isolament has accentuated the inequalities among students; the risks of increasing educational poverty are high ( Save-the-Children, 2020) and force us to rethink and build new relationships with the territory, families, and social actors. The central issue of the return to school will therefore be to activate an inclusive challenge, favoring active and alternative teaching practices, peer education among children, new cooperative experiences, and research-action practices starting from the potential of each one (Ferrante, Passerini, \& Palmieri, 2020), enhancing talents and promoting spaces of participation and democracy.

\section{ACKNOWLEDGEMENTS}

The introduction is by Massimiliano Fiorucci, paragraphs 2 and 2.2., edited by Lisa Stillo; paragraphs 2.1 and 2.3 by Giorgio Crescenza; paragraph 3 is edited by Maria Concetta Rossiello. Paragraph 4 was written collectively by all authors.

\section{REFERENCES}

Save-the-Children. (2020). L'impatto del coronavirus sulla povertà educativa. Retrieved from https://s3.savethechildren.it/public/files/uploads/pubblicazioni/limpatto-del -coronavirus-sulla-poverta-educativa_0.pdf

Bailey, K. D. (1994). Methods of Social Research (fourth edition). New York: The Free Press.

Baldacci, M. (2014a). La realtà educativa e la ricerca-azione in pedagogia. Educational, Cultural and Psicological Studies(9). https://doi.org/10.7358/ecps-2014-009-bald

Baldacci, M. (2014b). Per un'idea di scuola. Istruzione, lavoro e democrazia. Milano: Franco Angeli.

Baldacci, M. (2020). La pandemia e il fallimento della scuola-azienda. Micro-Mega(4), 121130.

Benvenuto, G. (2015). Stili e metodi della ricerca educativa. Roma: Carocci.

Bruzzone, D. (2016). L'esercizio dei sensi. Fenomenologia ed estetica della relazione educativa. MIlano: Franco Angeli.

Calvani, A. (2017). Manuale di tecnologia dell'educazione. Pisa: Edizioni ETS.

Calvani, A. (2019). Che cos'è la tecnologia dell'educazione. Roma: Carocci.

Cambi, F. (2006). Le pedagogie del Novecento. Roma-Bari: Editori Laterza.

Carruba, M. C. (2014). Tecnologia e Disabilità. Pedagogia speciale e tecnologie per un'inclusione possibile. Lecce: Pensa Multimedia.

Chiosso, G. (2011). Alfabeti d'Italia. La lotta contro l'ignoranza nell'Italia unita. Torino: Società Editrice Internazionale.

Cohen, L., Manion, L., \& Morrison, K. (2007). Research Methods in Education. Sixth edition. Oxon: Routledge.

Corbetta, P. (2003). La ricerca sociale: metodologia e tecniche. Bologna: il Mulino.

Covato, C. (1996). Un'identità divisa. Diventare maestre in Italia fra Otto e Novecento. Roma: Archivio Guido Izzi.

Creswell, J. W. (2014). Qualitative inquiry \& research design. Choosing Among Five Approaches. Second Edition. London: Sage.

Dewey, J. (1915). The School and Society. Chicago: The University of Chicago Press.

Doniti, P. (2015). L'enigma della relazione. Bologna: Edizioni Mimesis. 
Ferrante, A., Passerini, M. B. G., \& Palmieri, C. (2020). L'educazione e i margini. Temi, esperienze e prospettive per una pedagogia dell'inclusione sociale. Milano: Guerini.

Ferrari, M. (2020). L'educazione esclusiva. Pedagogia della distinzione sociale tra XV e XXI secolo. Brescia: Scholé.

Frabboni, F. (2009). Sognando una scuola normale. Palermo: Sellerio.

Franco, G. D. (2010). Il campionamento nelle scienze umane. Teoria e pratica. Milano: Franco Angeli.

Margiotta, U. (2018). La formazione dei talenti. Tutti i bambini sono un dono, il talento non è un dono. Milano: Franco Angeli.

Milani, L. (2014). Competenza pedagogica e progettualità educativa. Brescia: La Scuola.

Montessori, M. (2000). L'autoeducazione. Milano: Garzanti-Elefanti.

Pati, L. (2008). La corresponsabilità educativa tra docenti e genitori. Milano: Pedagogia e Vita.

Raja, D. S. (2016). Bridging the disability divide through digital technologies. Background Paper for the 2016 World Development Report: Digital Dividends. World Bank Group.

Rivoltella, P. C. (2020). Superare facili contrapposizioni. In presenza o a distanza la didattica merita di più (Vol. 27). Retrieved from https://www.glonaabot.it/articoli-correlati/ superare-facili-contrapposizioni-in-presenza-o-a-distanza-la-didattica-merita-di-piu

Roncaglia, G. (2020). Cosa succede a settembre? Scuola e didattica a distanza ai tempi del COVID-19. Roma-Bari: Laterza.

Unterhalter, E. S., \& North, A. (2017). Education, Poverty and Global Goals for Gender Equality: How People Make Policy Happen. Abingdon: Routledge.

Volpicella, A. M. (2017). Una bussola per la scuola. Nuove strategie pedagogiche e didattiche per gli studenti di oggi (A. M. Volpicella \& G. Crescenza, Eds.). Roma: Edizioni Conoscenza.

Volpicella, A. M. (2020a). Apprendere a insegnare. Competenze e sensibilità della professione docente (A. M. Volpicella \& G. Crescenza, Eds.). Roma: Edizioni Conoscenza.

Volpicella, A. M. (2020b). Sapere. Fare. Essere. Nella scuola di oggi. In A. M. Volpicella \& G. Crescenza (Eds.), Apprendere a insegnare. Competenze e sensibilità della professione docente (pp. 25-70). Roma: Edizioni Conoscenza. 